\title{
DETERMINANTS OF CORPORATE BOND AND SUKUK RATINGS IN INDONESIA
}

\author{
Afifatun Ni'mah ${ }^{1}$, Nisful Laila ${ }^{2}$, Sylva Alif Rusmita ${ }^{3}$ and Eko Fajar Cahyono \\ ${ }^{1}$ Universitas Airlangga, Indonesia, afifatun.nimah-2015@feb.unair.ac.id \\ ${ }^{2}$ Universitas Airlangga, Indonesia, nisful.laila@feb.unair.ac.id \\ ${ }^{3}$ UniversitassAirlangga, Indonesia, sylvalifr@feb.unair.ac.id \\ ${ }^{4}$ Corresponding Author, Universitas Airlangga, Indonesia, ekofajarc@feb.unair.ac.id
}

\begin{abstract}
This study aims to determine the factors, both financial and non-financial, which influence corporate bond and Sukuk ratings. The results will be useful for companies, investors or related parties as additional information and references for their investment decisions. Using ordinal logistic regression models with SPSS version 21 software, the study analyses the determinants of corporate bond and sukuk ratings listed on the Indonesia Stock Exchange (IDX) for the period 2013-2017. The variables employed are profitability, liquidity, leverage, company size, securities structure and maturity date. The results of the Wald test statistics show that leverage ratio, firm size, security structure, and maturity date are the factors that influence the probability of high or low corporate bond ratings, while profitability and liquidity ratios are factors that have no effect on the level of such ratings. With regard to sukuk, profitability, liquidity, and maturity date are the factors that influence the probability of high or low corporate sukuk ratings, while leverage ratio, company size, and security structure have no effect on the ratings.
\end{abstract}

Keywords: Corporate bond, Corporate sukuk, Determinant rating, Indonesia. JEL Classification: G11; G23; G32; G41.

Article history:

Received : September 25, 2019

Revised : May 12, 2020

Accepted : July 6, 2020

Available online : August 25, 2020

https://doi.org/10.21098/jimf.v6i3.1106 


\section{INTRODUCTION}

\subsection{Background}

The capital market operates in an organised manner to bring together deficits and surplus parts . It plays an important role for businesses (companies) seeking capital for expansion. One way of obtaining additional funds is by issuing financial instruments that can be traded on the capital market, such as bonds, sukuk and shares. Sukuk are instruments traded on the Islamic capital market, with all the operational activities and mechanisms of the market based on application of sharia principles that protect from riba, maysir, gharar, and bathil (Hamida, 2017). Sukuk serve as a vital tool for mobilising financial resources and are a key instrument for financial development in Islamic economics. Bonds can be classified as debt securities in addition to sukuk.

Comparisons between sukuk and conventional bonds have been made by several researchers; for example, Alam et al. (2013) compared global market reactions to bonds and sukuk before, during and after the global financial crisis. Data were taken from the Malaysian context and their results show that both types of debt securities had similar market reactions.

This financial instrument is very important for investors when considering the risks they will face when owning the instrument. To date, financial instruments that are known to be safe and promise fixed income in the capital market are bonds and sukuk, but investors often face information problems related to the characteristics of bond and sukuk issuing companies; such characteristics include factors that will determine the risks faced by investors. Errors in interpreting company information can lead to failure to invest, making some investors reluctant to reinvest.

One easy way to anticipate investment failure is to read information about a company's financial performance, which can be used as a vital reference for accountability in managing investors' funds (Pebruary, 2016). Moreover, investors can refer to the bond and sukuk ratings issued by securities rating agencies. These ratings are used to communicate company performance and can also determine whether the company is feasible or not feasible for investment (investment or not investment grade). A good company rating is a good sign for investors regarding its ability to determine the timeliness of the payment of the principal value of bonds and sukuk, which reflects the level of risk of all bonds and sukuk traded. Through the ratings of securities, investors can measure the level of risk and return on investments made (Hamida, 2017).

Companies with good securities ratings will be more profitable because they will be more trusted by investors, and they will obtain many benefits if they have high ratings. Therefore, to achieve a high company ranking, company stakeholders must know what factors can influence corporate bond and sukuk ratings (Widiastuti \& Rahyuda, 2016). To the best of the author's knowledge, no paper has examined the determinants that can effect bond and sukuk ratings in Indonesia using the financial statement and more that non financial statement variable. 


\subsection{Objective}

Based on the discussion above, this study aims to consider whether profitability, liquidity, leverage, firm size, sukuk and bond structure, and maturity date affect the probability of high or low bond and corporate sukuk ratings. The research was conducted to fill the gap in the literature; for example, by adding variables of the securities structure (Arundina et al., 2015) and maturity date (Sudaryanti et al., 2014) of sukuk and bonds as non-financial variables. The results of the study are expected to be useful by strengthening the empirical studies on the determinants of corporate bond and sukuk ratings. In addition, the research is also expected to be useful for companies, investors or related parties as additional information and references for investing.

This research employed data from the period 2013 to 2017 ; over the five years in question, the capital market can be said to have continued to grow. There is interest among investors to buy and sell on the capital market, including bond and sukuk instruments, which resulted in a significant development in trading activities in 2017. Based on data published by OJK, the volume of corporate bond trading has continued to increase (Figure 1). In addition, based on the total value of sukuk issued in Indonesia (Figure 2), it has also experienced fairly good growth; although the proportion is relatively small compared to bonds, the growth of sukuk issuance is quite high.

\section{LITERATURE REVIEW}

\subsection{Theoretical Review}

\subsubsection{Signalling Theory}

According to Brigham and Houston (2006), cues or signals are actions that companies take to influence decisions or give instructions to investors about how management views company prospects. Such signals are in the form of information issued by a company about promotion or performance information which indicates its situation. This information is important for potential investors and actor's business or external aspects of the company, because it presents information, notes or illustrations about past and present circumstances and also future survival of the company, and how the situation has an effect on it .

Complete, relevant, accurate and timely information is needed by investors in the capital market as an analytical tool for making investment decisions. If information announced is positive, it is hoped that the market will have a positive reaction at the time of the announcement, showing that the information has been accepted by the market. Signalling theory is also useful in providing information in order to avoid information asymmetry with parties external to the company. Later, this information can therefore be accounted for by the company because it knows more much more about its condition and the prospects originating from external parties (investors and creditors).

After information has been announced by external parties, a company will first interpret and analyse it as a good signal (good news) or bad signal (bad news). A good signal will provide high value to the company and at the same time protect investors so that they will be able to make informed investments. Automatisation of the trading volume of company securities will increase in line with good signals received by market participants. 
The relationship between the publication of information, either financial statements, financial conditions or social politics to fluctuations in the volume of trading securities, can be seen in market efficiency. Broadly speaking, signalling theory is closely related to information availability in financial statements, which can be used by investors to make decisions; such statements are therefore the most important part of a company's fundamental analysis. The ranking of companies that have gone public is also based largely on the ratio analysis of financial statements. Such analysis is made to facilitate the interpretation of the financial statements that have been presented by company management.

\subsubsection{Securities Ratings}

Securities ratings are regularly made by the Securities Ratings Agency, an institution which is a private company that ranks securities traded on the capital market. The purpose of such rating is to provide opinions (independent, objective and honest) regarding the risks of a security. Investors can use the securities ratings to measure investment risk and assess the level of credibility of a company. They are also useful for showing a company's performance or prospects.

When securities ratings fall, this indicates that companies are potentially failing to pay returns, which in turn will cause the price of securities to fall. This is also because the demand for securities weakens, as they are considered attractive by investors. In this paper, the reference ratings methodology developed by PT. Pemeringkat Efek Indonesia (PEFINDO) and PT. Fitch Ratings Indonesia (Fitch) was employed.

Pefindo was founded on December 21st, 1993 by the OJK and Bank of Indonesia and began making local government ratings in 2011. It is the only security ratings company owned by domestic shareholders, and has ranked many companies and securities traded on the Indonesia Stock Exchange (IDX).

Fitch is a subsidiary owned by Fitch Ratings Ltd. and is the only international ratings agency in Indonesia. PT. Fitch was established in 2005, and was licensed by Bapepam and Bank Indonesia in 2006. The company aims to bring international transparency standards to the ranking criteria and ratings process in the local market. Meanwhile, factors that can influence the bond and sukuk ratings of corporate companies can be seen through financial and non-financial aspects.

\subsection{Previous Studies}

The results of previous research conducted by Arundina et al. (2015) using Multinominal Logistics and Neural Network Inferences show that the Neural Network Model is stronger than Multinominal Logistics Regression in predicting sukuk rating with existing samples. The price of shares, sukuk structure, industry sector, guarantee status, return on assets, log GDP, long-term debt to total assets, subordination status, total debt to total assets, and the cash ratio are significant variables in sukuk ratings. However, according to the Wald test, sukuk structure, industry sector, guarantee status, and subordination status are not able to distinguish some rating categories (AAA, AA, A and BBB); while it is possible that they are unable to do so, they can possibly distinguish a class rating in addition to the category of BBB. 
Arundina and Omar (2010), using Multinominal Logistics Regression in the Malaysian context, found that the variables that had most influence on sukuk ratings were companies' guarantee and value of ROA, and that the variables that did not impact on ratings were total assets, long-term leverage, interest coverage, and current ratio.

On the other hand, in research conducted by Sudaryanti et al. (2014) using Ordinal Logistics Regression, the only determinant factor that influenced sukuk ratings was firm size, whereas the variables of firm size, profitability, liquidity, leverage ratio, and maturity date of more than five years affected bond ratings. Based on this, we aim to analyse several factors that can influence bond and sukuk ratings using Ordinal Logistic Regression for the case of Indonesia.

Elhaj et al. (2015) show that corporate governance, financial measures, and sukuk structure are the significant variables that influence sukuk ratings, while Rozi and Sofie (2010) found that the variables that influenced the prediction of sukuk ratings were company liquidity, leverage ratio, and auditor reputation (opinion). Growth, firm size, profitability of the company, sinking funds, and collateral (security) were variables that did not impact on sukuk ratings.

In Saputri's (2017) Effect of Performance Financial to Rating Sukuk of Using Regression Multinomial Logistics Model, the financial performance results had a significant effect on sukuk ratings. In the first model, ROA and current ratio had a positive effect on the rating category idea compared to the ideal rating. In the second model, ROA and current ratio also impacted positively on the rating idAA compared to idAAA.

According to Sari and Yasa (2016), the good corporate governance and company liquidity ratios had a positive and significant effect on bond ratings, while profitability ratios had no effect. Sucipta and Rahyuda (2015) found that company growth, liquidity and maturity partially influenced positively and significantly the bond ratings issued by PT. PEFINDO for companies on the Indonesia Stock Exchange in the 2009-2012 period. In addition, Widiastuti and Rahyuda (2016) found that partial growth of the company and the liquidity ratio affected bond ratings negatively, but not significantly, while maturity had a significant positive effect on bond ratings, and the activity ratio had a positive, but not significant, effect on bond ratings. At the same time, growth of the company, liquidity ratio, maturity, and theactivity ratio influenced bond ratings significantly. Sari and Yas (2016), Sucipta and Rahyuda (2015) and Widiastuti and Rahyuda (2016) was analysis the corporate bond only not sukuk corporate and have similar research method. The main difference between this study and previous ones is the objective : we examine the rating determinants of both conventional and sukuk corporate .

Borhan and Ahmad (2018) established that just three variables significantly impacted sukuk ratings. Their results demonstrate that a guaranteed Sukuk Ijarah or Sukuk Musyarakah issued by a highly profitable firm have a higher likelihood of obtaining an AAA or AA rating compared to an A. A type sukuk, particularly Sukuk Murabahah, are the most significant variable influencing sukuk ratings. However, firm size is not a significant determinant of sukuk ratings in this context.

With regard to the research gap, the objective of previous studies, such as those of Arundina et al. (2015), Elhaj et al. (2015), Rozi and Sofie (2010) and Saputri (2017) has not been a comparison between corporate and sukuk bonds. The other 
novelty is the securities structure variable compared to Sudaryanti et al. (2014), who only used firm size, profitability, liquidity, leverage ratio, and maturity date. The research data were the most up-to-date from the period 2013-2017.

\subsection{Conceptual Framework}

Figure 1 shows the analysis models for the independent or exogenous variables $(X)$, namely financial and non-financial factors, and for the dependent or endogenous variables $(\mathrm{Y})$, namely corporate bonds and sukuk ratings.

Financial

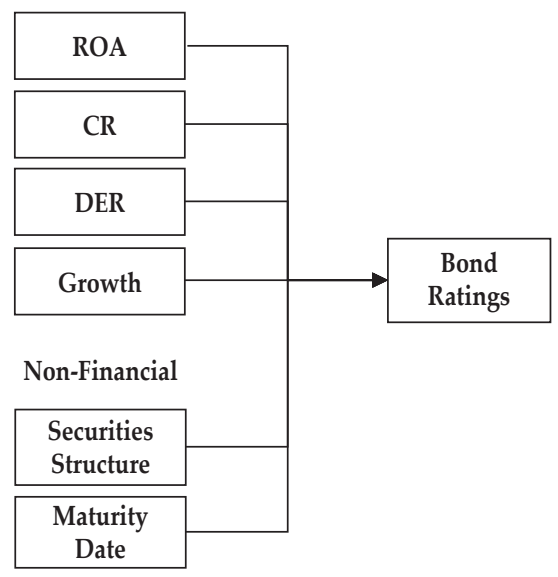

Financial

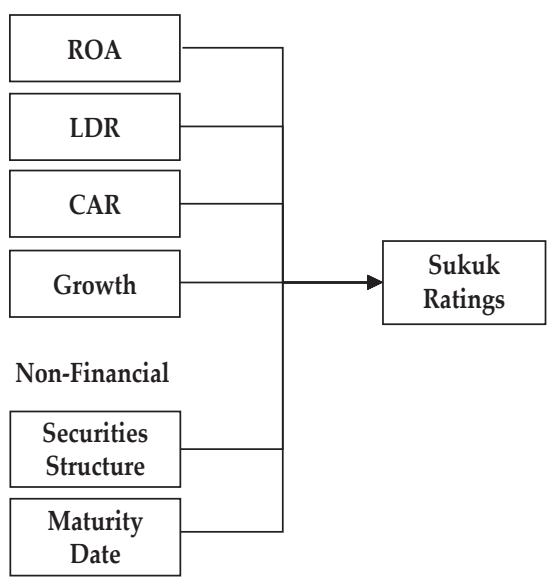

Figure 1.

Bond and Sukuk Rating Analysis Models

\section{a. Return on Assets Ratio (ROA)}

ROA reflects a company's profits. The higher the ROA value, the higher the profit, meaning company performance is improving (Brigham \& Houston, 2006). This ratio shows the rate of return for all investors (Brigham \& Houston, 2010). (Borhan \& Ahmad, 2018 ). Qizam and Fong (2019) found that sukuk and bond ratings were influenced by ROI (Return on Investment), and that ROI and ROA had significant correlation.

\section{b. Current Ratio (CR)}

CR is a liquidity tool that reflects a company's ability to pay off its current liabilities on the total assets it owns (Brigham \& Houston, 2006).

\section{c. Loan to Deposit Ratio (LDR)}

This ratio is used as a tool to measure liquidity in the banking industry. The LDR reflects the ability of banks to meet their short term obligations (Adhidarma \& Purbasari, 2015). The ratio is also used to see bank management in allocating customer or third party funds (Riyadi et al., 2015). 
d. Debt to Equity Ratio (DER)

DER reflects the financial position of a company based on its level of debt (Brigham \& Houston, 2006).

\section{e. Capital Adequacy Ratio (CAR)}

CAR is used to measure leverage in the banking industry. It reflects the ability of banks to provide funds used to overcome possible default risk (Adhidarma \& Purbasari, 2015). Research comparing sukuk and bond ratings in several countries was conducted by Qizam and Fong (2019), who found that financial disclosure quality and accounting-based risk, such as leverage and ROI, affected sukuk ratings in Indonesia and Malaysia and bond ratings in Australia. Bond ratings were more influenced by variations in financial performance than sukuk ratings. Elhaj et al. (2019) also demonstrated that financial leverage was negatively related to financial measures and sukuk ratings.

\section{f. Growth}

The size of a company, together with growth of total assets, is an indicator of company security and collateral. High growth will give broad access to finance compared to low growth. Companies with high growth will also have a good level of financial flexibility, allowing them to minimise default risk for investors. Growth also affects a company's ability to manage its assets (Widiastuti \& Rahyuda, 2016).

\section{g. Securities Structure}

Different types of bonds and sukuk are issued by companies, based on the classification of value, maturity date, and return. Therefore, the risk and level of return of investors will not be the same for each type of debt securities. The Malaysian Rating Corporation Berhad (MARC a, b, 2012) states that the ratings for each type of debt effect issued by a company are not the same with regard to the level of investment security and predictability return. Therefore, the structure of securities can be used as a determinant of sukuk and bond ratings (Arundina et al., 2015). Elhaj et al. (2019) showed that sukuk ijarah is positively related to the sukuk structure and sukuk rating relationship. Their empirical findings are based on a sample of 25 Malaysian publicly traded firms rated by the Malaysian RAM and MARC rating agencies, equivalent to S\&P, over the 2008 to 2012 period.

\section{h. Maturity Date}

The maturity date is the date on which the debt security holder receives repayment of the nominal value of the securities owned (Brigham, 2010).

\section{METHODOLOGY}

The study employs a quantitative approach through the testing of hypotheses. The purpose of the research is to establish whether there is a relationship between financial (profitability ratios, liquidity ratios, leverage ratios, and firm size) and non-financial (securities structure and maturity) factors in determining the probability of high or low corporate bond and sukuk ratings. 


\subsection{Data}

The research data are yearly from 2013 to 2018, comprising bonded and sukuk outstanding accessed from the Indonesia Stock Exchange website. Financial statements were also partly accessed from the Indonesia Stock Exchange, and also from the websites of each company that issued the securities. Company ratings are based on the ratings history of the company conducted by PT. PEFINDO and PT. Fitch Ratings Indonesia.

The research population is companies in Indonesia which issued bonds and sukuk during the period 2013-2018. The sampling technique was purposive sampling, which is a technique with certain considerations (Lavakras, 2008), used so that research has limitations to its observations. The sample criteria were as follows:

1. Corporate bonds and sukuk placed on the Indonesia Stock Exchange during the period 2013-2018.

2. Corporate bonds and sukuk rated by the PT. Indonesian Ratings Agency and PT. Fitch Ratings Indonesia.

3. The issuers or issuing and sukuk companies have reports audited Financials for the period 31 December 2013-2018 (six years ).

4. The financial statements are rupiah-denominated.

The study population is Indonesian companies listed on the IDX that issued bonds and sukuk during the 2013-2018 period. The sampling technique was purposive sampling. Based on the criteria, 16 corporate companies issuing bonds and sukuk were chosen, with 270 types of bond and 280 types of sukuk selected as samples. Ratios of the variable measurement indicators were taken based on the financial statements accessed through the website of each company. The sample data can be seen in Appendix .

\subsection{Model Development}

An ordinal regression model was employed, which hypothesised that at least six factors influenced corporate bond or sukuk ratings:

$$
\operatorname{Logit}(i)=\alpha(i)+\beta 1 X 1+\beta 2 \times 2+\beta 3 X 3+\beta 4 X 4+\beta 5 X 5+\beta 6 \times 6
$$

where:

Logit(i) : Probability of corporate bonds/sukuk for rating $i$

$\alpha(i) \quad$ : Constant for rating category $i$

$\beta \quad$ : Coefficient

X1 : Sukuk/Bond Structure

X2 : Maturity

X3 : Return on Assets

X4 : Current Ratio

X5 : Growth

X6 : Debt to Equity Ratio

Based on the analysis of the two models shown in Figure 1 and Equation 1, six factors influence corporate bond and sukuk ratings, comprising four financial factor variables and two non-financial ones. The financial factor data were obtained 
from the companies' annual financial reports in rupiah, partly accessed from the Indonesia Stock Exchange and partly from the websites of each company issuing the securities. Equation 1 is a replication of the model of Arundina et al. (2015) and Sudaryanti et al. (2014). However, previous research does not compare several ratings, so logit is not division. Some variables were also taken and compared with the research conducted by Sudaryanti et al. (2014). Based on these equations, the output produced is as follows:

\section{a. Bond Model}

Logit (rating category $\mathrm{BBB}, \mathrm{BBB}+, \mathrm{A}-, \mathrm{A}, \mathrm{A}+, \mathrm{AA})=\alpha(i)+\beta 1$ fixed interest bond $+\beta 2$ Maturity $+\beta 3 \mathrm{ROA}+\beta 4 \mathrm{CR}+\beta 5$ growth $+\beta 6 \mathrm{DER}$.

\section{b. Sukuk Model}

Logit (rating category $\mathrm{A}, \mathrm{A}+, \mathrm{AA})=\alpha(\mathrm{i})++\beta 1$ sukuk ijarah $+\beta 2$ Maturity $+\beta 3 \mathrm{ROA}$ $+\beta 4 \mathrm{CR}+\beta 5$ growth $+\beta 6 \mathrm{DER}$.

\subsection{Analysis Methods}

Ordinal logistic regression is one method used to look for influences or relationships between exogenous or independent variables $(X)$ and endogenous or dependent variables $(Y)$. In ordinal logistics, the latter use data in the form of levels (an ordinal scale). This model is suitable for this study, as it is unaffected by the loss of levels in endogenous or dependent variables $(Y)$.

The method used to estimate parameters in ordinal logistic regression is that of maximum likelihood. This is employed to explain the chance of observing as a function of unknown parameters, which can be built with a function called the likelihood function (Hosmer \& Lemeshow, 2000). The stages of testing in the ordinal logistic regression model are followed by three statistics, namely the goodness of fit test, the coefficient of determination test, and the Wald test.

The endogenous or dependent (Y) variables used were sukuk and bond ratings based on the ratings issued by the ratings agencies PT. Pemeringkat Efek Indonesia and PT. Fitch Ratings Indonesia. The ID code or IDN indicates that the company issuing sukuk and bonds is an Indonesian company. The selected categories are as follows:

Table 1.

Operational Definition of Endogenous or Dependent Variables (Y)

\begin{tabular}{lccccccc}
\hline \multirow{2}{*}{ Securities } & \multicolumn{7}{c}{ RATINGS } \\
\cline { 2 - 8 } & AAA & AA+ & AA & A+ & A & A- & BBB+ \\
\hline Bonds & $\sqrt{ }$ & $\sqrt{ }$ & $\sqrt{ }$ & $\sqrt{ }$ & $\sqrt{ }$ & $\sqrt{ }$ & $\sqrt{ }$ \\
Sukuk & $\sqrt{ }$ & $\sqrt{ }$ & $\sqrt{ }$ & $\sqrt{ }$ & $\sqrt{ }$ & $\sqrt{ }$ & \\
\hline
\end{tabular}

Source: Indonesia Stock Exchange

The ratings categories used in this study, as shown in Table 1, are bond ratings ranging from the highest $\mathrm{AAA}$, to $\mathrm{AA}+, \mathrm{AA}, \mathrm{A}+, \mathrm{A}, \mathrm{A}$ - and $\mathrm{BBB}+$. The sukuk rating categories used start from the highest, $\mathrm{AAA}$, to $\mathrm{AA}+, \mathrm{AA}, \mathrm{A}+, \mathrm{A}$, and $\mathrm{A}-$. The bond 
and sukuk ratings only differ with regard to the $\mathrm{BBB}+$ rating, due to the limited sample data on outstanding sukuk in the period 2013-2017 with BBB+ ratings.

The exogenous or independent variables $(X)$ related to financial factors using ratios were taken from the company's financial statements. Non-financial factors can also be identified directly on the effect. Table 2 shows a description of the exogenous or independent variables $(X)$.

Table 2.

Operational Definition of Exogenous or Independent Variables (X)

\begin{tabular}{|c|c|c|}
\hline Variable & Variable Scale & Indicator \\
\hline Return on assets ratio & Ratio & $\mathrm{ROA}=\frac{\text { net profit }}{\text { total assets }}$ \\
\hline Current ratio (bonds) & Ratio & $\mathrm{CR}=\frac{\text { current assets }}{\text { current liabilities }}$ \\
\hline Loan to deposits ratio (sukuk) & Ratio & $\mathrm{LDR}=\frac{\text { total credit (non-bank third parties) }}{\text { total third party funds }}$ \\
\hline Debt to equity ratio (bonds) & Ratio & $\mathrm{DER}=\frac{\text { total debt }}{\text { total equity }}$ \\
\hline Capital adequacy ratio (sukuk) & Ratio & CAR $=\frac{\text { capital }}{\text { risk weighted assets (AMTR) }}$ \\
\hline Growth & Ratio & Growth $=\frac{\text { total assets }(\mathrm{t}) \text {-total assets }(\mathrm{t}-1)}{\text { total assets }(\mathrm{t}-1)}$ \\
\hline \multirow{2}{*}{ Securities structure } & \multirow{2}{*}{ Nominal } & $\begin{array}{l}1=\text { fixed interest bonds } \\
2=\text { subordinated bonds }\end{array}$ \\
\hline & & $\begin{aligned} & 1=\text { ijarah sukuk } \\
2= & \text { mudharabah sukuk }\end{aligned}$ \\
\hline Maturity date & Nominal & $\begin{array}{l}1=1 \text { year } \\
2=3 \text { years } \\
3=5 \text { years } \\
4=6 \text { years } \\
5=7 \text { years } \\
6=10 \text { year }\end{array}$ \\
\hline
\end{tabular}

Source: Ministry of Finance, report on investor dedication relationship (2012).

\section{RESULTS AND ANALYSIS}

\subsection{Results}

The study has aimed to ascertain the effect of the return on assets ratio, current ratio, loan to deposits ratio, capital adequacy ratio, debt to equity ratio, growth, security structure, and maturity date on the bond and sukuk ratings of corporate companies listed on the Indonesia Stock Exchange during the period 2013-2018. The analysis technique used was the ordinal logistic regression model, using SPSS version 21 (for Windows). The significance level of the alpha used was 0.05 ( $\alpha=$ $5 \%)$, or the level of trust was 0.095 (95\%).

\section{Goodness of Fit Test}

A goodness of fit test was conducted to establish whether the resulting model was feasible for use or not. Table 3 shows the test results based on deviance statistics: 
Table 3.

Goodness-of-Fit

\begin{tabular}{lccc}
\hline Model & Chi-Square & df & Significance \\
\hline Bond model & 157.344 & 381 & 1.000 \\
Sukuk model & 114.465 & 203 & 1.000 \\
\hline
\end{tabular}

If the significance is $\leq 0.05(\alpha \leq 5 \%)$, this means that the resulting model is unable to follow the pattern within the available data, whereas if the significance value is $\geq 0.05(\alpha \geq 5 \%)$, then the resulting model is feasible for use in the hypothesis testing. According to the test results, with significance values of 1.000 and 0.999 for the deviance value of bonds and sukuk respectively, meaning that the significance value is $\geq 0.05(\alpha \geq 5 \%)$, it can be concluded that the ordinal regression model is suitable for use with the bond and sukuk sample data. Therefore, the resulting model can be used for the hypothesis testing.

\section{Coefficient of Determination}

Table 4.

Pseudo R-Square

\begin{tabular}{lc}
\hline Model & COX AND SNELL $\mathbf{R}^{2}$ \\
\hline Bond model & 0.859 \\
Sukuk model & 0.578 \\
\hline
\end{tabular}

Table 4 shows the value of $\mathrm{R}^{2}$, which explains the amount of information in the endogenous or dependent variables $(\mathrm{Y})$ that can be explained or influenced by the exogenous or independent variables $(\mathrm{X})$. The coefficient of determination can be seen in the pseudo R-square table with the Cox and Snell values. The table shows that the Cox and Snell value of $\mathrm{R}^{2}$ for bonds is 0.859 . This means that the six factors included in the model are able to explain or influence $85.9 \%$ of the information within the bond rating determinant, while the remaining $14.1 \%$ is influenced by other unknown variables. The Cox and Snell $\mathrm{R}^{2}$ for sukuk is 0.578 , which means that $57.8 \%$ of the information within the sukuk rating determinant can be explained by the resulting model, while the remaining $42.2 \%$ is influenced by other unknown variables.

\section{Wald Test}

If the level of significance in the variable is $\leq 0.05(\alpha \leq 5 \%)$, it can be concluded that the independent or exogenous variable $(X)$ is able to partially influence the dependent or endogenous variable (Y). However, if the level of significance has a value of $\geq 0.05(\alpha \geq 5)$, it can be concluded that the independent or exogenous variable $(X)$ is unable to partially influence the dependent or endogenous variable (Y). 
Table 5.

Parameter Estimates of Bonds

\begin{tabular}{llccccc}
\hline & & ESTIMATE & $\begin{array}{c}\text { STD. } \\
\text { ERROR }\end{array}$ & WALD & DF & SIG. \\
\hline \multirow{3}{*}{ Ratings (Y) } & BBB+ & 7.727 & 2.689 & 8.258 & 1 & .004 \\
& BBB & 8.281 & 2.687 & 9.499 & 1 & .002 \\
& A- & 11.011 & 2.785 & 15.630 & 1 & .000 \\
& A & 17.014 & 3.487 & 23.815 & 1 & .000 \\
& A+ & 19.445 & 3.707 & 27.516 & 1 & .000 \\
& AA & 2212 & 4063 & 29.884 & 1 & .000 \\
\hline & & & & & & \\
& ROA & 11.118 & 23.547 & .223 & 1 & .637 \\
& CR & 5.901 & 1.926 & 9.390 & 1 & .002 \\
& Growth & .306 & 1.262 & .059 & 1 & .808 \\
& DER & 24.657 & 4.705 & 27.460 & 1 & .000 \\
& Fixed interest bond & 8.637 & 1.681 & 26.397 & 1 & .000 \\
Determination of & Subordinated bond & 0 &. &. & 0 &. \\
bond ratings $(X)$ & 1 year maturity & 8.552 & 1.740 & 24.165 & 1 & .000 \\
& 2 year maturity & 0 &. &. & 0 &. \\
& 3 year maturity & -18.082 & 1.312 & 190.001 & 1 & .000 \\
& 5 year maturity & -17.455 & .703 & 615.626 & 1 & .000 \\
& 6 year maturity & -14.633 & 1.533 & 91.141 & 1 & .000 \\
& 7 year maturity & -18.156 & .000 &. & 1 &. \\
& 10 year maturity & 0 &. &. & 0 &. \\
\hline
\end{tabular}

In Table 5, it can be seen that three variables have a significance value of $\leq 0.05$ ( $\alpha \leq 5 \%)$, namely the current ratio, debt to equity ratio and bond structure. This means that these variables can influence the probability of high or low corporate bond ratings significantly. There are also three variables which have a significance value of $\geq 0.05(\alpha \geq 5 \%)$ : maturity, ROA and growth. This indicates that these variables cannot significantly influence the probability of high or low corporate bond ratings.

Table 6.

Parameter Estimates of Sukuk

\begin{tabular}{ccccccc}
\hline & & \multirow{2}{*}{ ESTIMATE } & $\begin{array}{c}\text { STD. } \\
\text { ERROR }\end{array}$ & WALD & DF & SIG. \\
\hline \multirow{4}{*}{ Ratings (Y) } & & & & & \\
& A- & -6.131 & 0.761 & 64.842 & 1 & 0.000 \\
& A & -5.746 & 0.742 & 59.898 & 1 & 0.000 \\
& A & -7.636 & 1.407 & 29.476 & 1 & .000 \\
& A+ & -7.117 & 1.370 & 26.976 & 1 & .000 \\
& AA & -4.978 & 1.217 & 16.719 & 1 & .000 \\
\hline
\end{tabular}


Table 6.

Parameter Estimates of Sukuk (Continued)

\begin{tabular}{|c|c|c|c|c|c|c|}
\hline & & ESTIMATE & $\begin{array}{c}\text { STD. } \\
\text { ERROR }\end{array}$ & WALD & DF & SIG. \\
\hline \multirow{12}{*}{$\begin{array}{l}\text { Determination of } \\
\text { sukuk ratings }(X)\end{array}$} & $\mathrm{ROA}$ & -83.509 & 21.072 & 15.705 & 1 & .000 \\
\hline & LDR & -1.565 & .959 & 2.663 & 1 & .103 \\
\hline & Growth & -2.820 & 1.790 & 2.483 & 1 & .115 \\
\hline & CAR & 1.167 & .243 & 22.995 & 1 & .000 \\
\hline & Ijarah sukuk & 2.085 & 6771 & 9.639 & 1 & .002 \\
\hline & Mudharabah sukuk & $0 \mathrm{~b}$ & . & . & 0 & . \\
\hline & 1 year maturity & .382 & 1.979 & .037 & 1 & .847 \\
\hline & 3 year maturity & 1.112 & 1.477 & .567 & 1 & .451 \\
\hline & 5 year maturity & -.540 & 1.437 & .141 & 1 & .707 \\
\hline & 6 year maturity & -25.041 & .000 & . & 1 & . \\
\hline & 7 year maturity & $1.378 \mathrm{E}-15$ & 1.551 & .000 & 1 & 1.000 \\
\hline & 10 year maturity & $0 \mathrm{~b}$ & . & & 0 & . \\
\hline
\end{tabular}

In Table 6, it can be seen that four variables have a significance value of $\leq 0.05$ ( $\alpha$ $\leq 5 \%$ ), namely maturity, ROA, debt to equity ratio and sukuk structure, meaning that they can significantly influence the probability of high or low corporate bond ratings. Only two variables have a significance value of $\geq 0.05(\alpha \geq 5 \%), C R$ and growth, which indicates that they cannot significantly influence the probability of high or low corporate bond ratings.

\subsection{Analysis}

\subsubsection{Analysis of Profitability}

The Wald test statistic ordinal logistic regression model for bonds in the ROA variable has a coefficient of 11.118 and a significance value of 0.637 . ROA could increase the chance of obtaining a high rating, but it would not be significant at the $5 \%$ level. Therefore, the relationship between the ROA variable and the probability of high or low corporate bond ratings is not significant. According to the theory , ROA is the main variable which causes bond ratings to rise, but the results of this study are contrary to this. It is possible that companies are not able to rotate assets optimally to generate profits and that ROA does not differ much each year. From the investors' point of view, ROA is important, but in this study it does not display many notable changes, thus discouraging investors from buying sukuk, and meaning sukuk ratings do not increase. This finding was supported by another researcher, who mentioned the possibility that insignificant profitability was due to the low level of company ROA during the observation period, meaning the company only made low profits in the observation period (Sari \& Yasa, 2016).

With regard to sukuk, the ROA variable has a coefficient of -83.509 and a significance value of 0.000 . The effect of the $R$ variable on the probability of high or low corporate sukuk rating is therefore significantly negative. ROA is a reflection of the profits a company makes from net profits earned. The higher the ROA value, 
the higher the profit, meaning company performance is improving. In this study, ROA had a negative influence, contrary to the theory .

This can be excused by the concept of investor behaviour, in which investors want to make capital gains. They have the perception that when performance produces a high ROA it is the best time to make a profit by selling sukuk, thus benefitting from cap increases. Higher ROA triggers the demand for sukuk and makes its price on the secondary market increase. A high selling price encourages investors to sell sukuk; eventually, sukuk sales can cause their ratings to fall due to reduced holdings. This study obtained results similar to those of Affanadi and Affandi (2017), who found that investor behaviour and perceptions played a major role in the selling or buying of sukuk on the market, ultimately having an impact on rankings. This means that company profitability influences the probability of high or low corporate sukuk ratings is inversely proportional .

The other probability is every one digit increase in ROA reduces the probability of corporate sukuk ratings, and every one digit fall will increase the probability . In this case, when a company pays its debts on time, its returns will decrease, but its rating will continue to rise. Significant negative results on profitability are consistent with the research conducted by Sudaryanti et al. (2014).

\subsubsection{Analysis of Liquidity}

The Wald test statistic result in an ordinal logistic regression model for bonds in the CR variable has a coefficient of 5.901 and a significance value of 0.002 , so the relationship between the $\mathrm{CR}$ variable and the probability of high or low corporate bond ratings is significant. Bonds have a greater chance of obtaining higher ratings, in line with a high current ratio value. The liquidity ratio is used to measure a company's ability to meet its debts when debt maturity is issued. The current ratio also shows the efficiency of a company's operating cycle in turning products into cash. A high current ratio means that companies are more likely to be able to pay interest (short-term liabilities), which means they are more liquid. Therefore, the liquidity ratio variable increases, meaning the bond rating will also increase. This result is in accordance with the findings of Utami et al. (2017).

In the sukuk instrument, the calculation of the liquidity ratio is made using the loan to deposits ratio. Liability term this short related to the coupon payment or for the results sukuk. Consequently, good company liquidity is considered to reduce the risk of default on investors, thereby increasing corporate bond ratings. A company will obtain an investment grade category from a rating agency if it can effectively manage its liquidity level.

In addition, the results for sukuk related to the LDR variable show a coefficient of -1.565 and significance value of 0.103 , meaning the relationship between the LDR variable and the probability of high or low corporate sukuk ratings is not significant. The current ratio in this study is shown to reduce the chance of obtaining a higher sukuk rating, but not significantly. Moreover, the LDR does not effect the sukuk rating.

The LDR is a tool used to measure the ability of companies to give financing and liquidity. A high LDR could effect the liquidity of assets and could be a sign of problems in managing working capital. At the same time, the LDR may not 
directly effect the ability to pay the revenue share of sukuk holders, because it depends on the ability of companies to manage their assets and liabilities. Even if a company has a high LDR, if they are able to control the turnover of assets, so they are still able to pay their liabilities, it means the LDR will not directly affect sukuk ratings. Sukuk profit is centred on the ability to manage assets in order to make profits, which will subsequently be shared with investors. This finding is consistent with those of Kamarudin and Ghani (2014), that liquidity has two scenarios into sukuk rating, significant or insignificant; in this study, the current ratio does not have a significant effect on the sukuk rating.

\subsubsection{Analysis of Leverage}

The Wald test statistic result ordinal logistic regression model for bonds in the DER variable has a coefficient of 24.657 and a significance value of 0.000 . Therefore, the relationship between the DER variable and the probability of high or low corporate bond ratings is significantly positive. The debt to equity ratio is a measurement of the total assets of a company financed by debt. It shows the relationship between the amount of long-term loans provided by creditors and the amount of a company's own capital provided by its owners. In this study, the higher the DER, the higher the bond rating.

Companies that have considerable debt do not necessarily experience financial difficulties, although debt increases the risks that must be borne by them. With debt, companies can use external funds to meet their needs, meaning internal funds possessed can be used for other needs, allowing fund management to run well, with the expectation of generating higher profits. In addition, if a company does not use debt, it will instead experience a wide range of investment or business expansion.

Investment and expansion require large funds, so if internal funds need to be used, companies will require a long time to collect the funds needed, which will also use up their cash, which would be very risky. For the reasons above, companies that use debt to meet their needs actually have promising business activities, so bond investors will see that they are prosperous, and of course if investors have argued so the bond rating will increase.

The results for sukuk in relation to the CAR variable show a coefficient of 1.167 and a significance value of 0.000 , meaning the relationship between the variable and the probability of high or low corporate sukuk ratings is insignificantly positive. In this study, CAR significantly improved the sukuk rating, and consequently a company's ability to provide funds to pay returns. This is because capital is one of the strategies to develop a good capital structure, with the right composition of debt and equity. The possession of capital indicates that a company is preparing sources of funds for its operations, which also indicates that it has prospects for future business in order to make a profit. If a company's leverage is well maintained, sukuk investors will feel that the company will be able return the sukuk principal and provide the best returns. Sukuk profit-sharing for investors is based on how much the company can return, the returns and its ability to turn capital to generate profits. Companies that can manage their capital will have opportunities for expansion and investment in order to generate profits for investors, which is 
a reason for increased sukuk ratingd. The results of this study are supported by those of Hamid et al. (2014), who represented capital as a strategy in compiling the turnaround process, and with profit ultimately improving sukuk ratings.

\subsubsection{Analysis of Firm Size}

Wald test statistic ordinal logistic regression model for bonds in the growth variable has a coefficient of 0.306 and a significance value of 0.808 . The relationship between the growth variable and the probability of high or low corporate bond ratings is therefore insignificant, while growth reduces opportunities insignificantly. Growth in this study refers to the growth of assets. Asset growth does not cause changes in bond ratings, possibly because it is not the main consideration for investors when choosing bonds. Considering the growth of assets alone is certainly not sufficient; it is necessary to also take into account other variables such as liabilities. Many companies have large assets, but are less able to turn these into profits, so investors' views are insufficient to simply observe the growth of assets. On the other hand, asset growth is rarely significant, so investors consider other variables, such as the current ratio and DER.

The results for sukuk with regard to the growth variable show a coefficient of -2.820 and significance value of 0.115 . Consequently, the relationship between this variable and the probability of high or low corporate sukuk ratings is not significant. Asset growth does not cause changes to sukuk ratings, possibly because it is not the principal consideration of investors when choosing sukuk. Considering the development of assets alone is clearly not sufficient, so it is necessary to look at other variables such as the power of the troupe to act as its assets then that it can be a profit that is brought forth. On the other hand, asset growth that is not too large cannot directly affect sukuk ratings. These results are in line with the research of Hardwick et al. (2000), who state that their results could not be significant because the growth of company assets was small, so did not affect the model, and also with the results of the research by Borhan and Ahmad (2018), who also state that assets do not affect sukuk ratings.

\subsubsection{Analysis of Securities Structure}

Securities structure is included in the ordinal logistic regression model using the dummy variable, in which there is a bond structure consisting of a fixed interest bond with code 1 and a subordinated bond with code 2, and a sukuk structure consisting of ijarah sukuk with code 1 and mudharabah sukuk with code 2. A fixed interest bond is a type of bond that has a return value with fixed interest paid on the maturity date, whereas subordinated bonds are bonds that have a lower priority ranking compared to others in terms of liquidity. Ijarah sukuk are sukuk issued by a company with an ijarah agreement, and mudharabah sukuk are sukuk issued with a mudharabah agreement.

The results with regard to the ijarah sukuk variable show a coefficient of 2.085 and significance value of 0.002 , while the mudharabah sukuk variable has a coefficient of 0 and an infinite significance value $(\sim)$. This means that mudharabah sukuk have a higher probability of a corporate sukuk rating than ijarah sukuk, 
which have a non-significant negative value. Mudharabah sukuk have a lower probability of a corporate sukuk rating than ijarah sukuk, which have a significant positive value. The results of this study in line with the research conducted by Elhaj et al. (2015), which found that ijarah sukuk had a significant positive result in sukuk ratings.

Based on the results of the model, it is established that companies with Iiarah sukuk have the opportunity to obtain a higher rating. Sharif and Abdullah (2018) argue that with sukuk based on al-ijarah, basic assets can only be sold by sukuk originators based on market value. This might be viewed by investors as high risk if the value of the assets has decreased. Only in some instances, for example if the basic asset is property, does value continually appreciate. Ijarah sukuk sales always see their nominal value at maturity by considering the time value of the money effect. This term is frequently pushed by investors to offer protection from fluctuations in the value of basic assets. Investment-based sukuk (mudharabah) must clearly be more accepting of more volatile returns in accordance with the financial status of the sukuk issuer.

Therefore, sukuk ijarah has a higher probability of obtaining a valuation. This view is supported by Borhan and Ahmad (2018), Yaakub et al. (2011) and Ahmad and Rahim (2013), who state that the sukuk ijarah and sukuk have a positive sign in sukuk ratings.

Based on the results of the model, it is established that companies with fixed interest bonds have the opportunity to obtain higher ratings. The Wald test statistic results in ordinal logistic regression models in fixed interest bond variable has a coefficient of 8.637 and a significance value of 0.000 . The subordinated bond variable has a coefficient of 0 and an infinite significance value $(\sim)$. Therefore, fixed interest bonds have a higher probability of bond ratings than subordinated bonds. The possibility occurs that investors prefer fixed interest bonds because they will make a profit if the interest rate falls.

\subsubsection{Analysis of Maturity}

The maturity date is the due date on which a company pays the returns on bonds and sukuk to investors. It also indicates the period of time over which investors lose their liquidity and over which they receive a return on their investments. The longer the maturity date, the higher the probability that investors will lose their liquidity, but will receive a high probability return value.

The Wald test statistic results of the ordinal logistic regression model for bonds in the maturity date variable are significantly negative for the 3 year, 5 year, 6 year periods, whereas for 1 year maturity they are significantly positive. Shorter due dates tend to avoid the risk of a fall in the value of money and the principal of bonds return more quickly, so investors can rotate their assets for other investments. It can therefore be stated that for every increase of one year in the maturity date, the probability of corporate bond and sukuk ratings will be reduced. This means that the maturity date has an effect on the probability of high or low corporate bond .

Based on the Wald test, the results for sukuk in relation to the maturity date variable are insignificant for all levels of maturity. Theoretically, the maturity date affects the bond rating; the longer the maturity date, the higher the risk of a decline 
in the value of the bonds caused by rising interest rates. Maturity dates for sukuk are unlikely to be homogeneous for various types of sukuk; Ijarah sukuk tends to have shorter maturity dates (Azmat et al., 2017). Sharif et al. (2018) state that the principal value of sukuk when first invested and at the maturity date must have a value that falls and tends to fall in line with the validity of the time value of money. Based on the concept of long- and short-term debt securities, the shorter the sukuk maturity date, the more attractive it is to investors because they will have a quick rate of return of liquidity and avoid the risk of impairment, therefore longer maturity dates will encourage downgraded ratings. However, this research is not significant because investors may not see the maturity date in the long term; if the sukuk run an interest rate risk, investors can immediately sell the bonds and invest in deposits, without having to wait until the maturity date. In the research conducted by Sudaryanti et al. (2014) the results related to the maturity date for bonds are significant and negative, while those for sukuk are insignificant and negative. The selection of maturity date is based on the preferences and needs of each investor.

\section{CONCLUSION AND RECOMMENDATIONS}

\subsection{Conclusion}

Based on the results of the discussion, it can be concluded that leverage, firm size, security structure and maturity date affect the probability of high or low corporate bond ratings, while profitability and liquidity do not significantly influence it. Profitability, liquidity and maturity date have a significant negative effect on the probability of high or low corporate sukuk ratings, whereas leverage, firm size and securities structure do not significantly influence ratings. So fundamental of corporate bond are more effected to the bond rating rather than sukuk rating . Sukuk are based on a different concept to corporate bonds, primarily on the underlying assets of the company rather than debt.

\subsection{Recommendations}

The study has limitations regarding the sample, especially the sukuk sample used, because sukuk are a new product on the capital market. The range of sukuk ratings is also less varied. Therefore, sukuk need a different rating concept to that of bonds. For the refinement of the results of further research, the following suggestions are made:

\section{a. For Practitioners}

Companies that issue bonds and want to obtain a high rating or fall into the investment grade category must consider the following. First, they must pay attention to their level of leverage in order to remain stable, and which can also be used to pay returns to investors on the maturity date. Second, companies must also pay attention to their size. Larger ones must be well managed and their total assets should be stable and increase from year to year in order to pay returns to investors. Third, companies that issue sukuk and want to obtain high ratings or 
be included in the investment grade category must pay attention to their level of profitability, which should continue to increase in order to be used to pay returns. Fourth, companies must also maintain their level of liquidity in order to remain balanced with the level of returns to be paid. Fifth, for investors, the short life of securities can be used as an investment option because it has a high bond and sukuk rating opportunity, which will reduce the default risk.

\section{b. For Regulators}

The results of the study imply an impact on regulators, namely that they, or the government, must be careful when considering a sukuk or bond rating. Based on the results of this research, many factors affect such ratings. Regulators should therefore not only trust the rating agency fully and directly, but also look deeper into company performance.

\section{c. Further Research}

Further research could first use a sample with a number of balanced rating variations for each type of endogenous variable, balanced between bonds and sukuk, so that the results will be more valid when making the same comparison. For example, of a bond using the BBB+ rating, it means that sukuk must also use the $\mathrm{BBB}+$ rating with the same amount. Second, it could also include a sample with a more balanced securities structure so that the results from the model can be clearly distinguished. Third, types of banking and non-banking industry sectors could be distinguished for more valid results as a result of different ratio calculations.

\section{REFERENCES}

Abdul Hamid , N. H., Zakaria, N. B., \& Ab Aziz, N. H. (2014). Firms' Performance and Risk with the Presence of Sukuk Rating as Default Risk. Procedia - Social and Behavioral Sciences, 145, 181-188.

Adhidarma, G., \& Purbasari, D. (2015). Memahami Hubungan antara Investasi dan GDP . Retrieved from Macroeconomic Dashboard Fakultas Ekonomika dan Bisnis UGM: http://macroeconomicdashboard. feb. ugm. ac. id/memahamihubungan-antara-investasi-dan-gdp.

Affandi, S. (2019). The Impact of Financial Measures, Earnings Management and Sukuk Structure on Sukuk Rating .

Ahmad, N., \& Rahim, S. A. (2013). Sukukijarah vs. sukuk musyarakah: Investigating Post-crisis Stock Market Reactions. International Journal of Humanities and Management Sciences (IJHMS), 1(1), 87-91.

Alam, N., Hassan, M. K., \& Haque, M. A. (2013). Are Islamic Bonds Different from Conventional Bonds? International Evidence from Capital Market Tests. Borsa Istanbul Review, 13(3), 22-29.

Arundina, T., \& Omar, M. A. (2010). Determinant of Sukuk Rating; The Case of Malaysia. Thesis Kulliyah of Economics and Management Science, International Islamic University Malaysia. 
Arundina, T., Omar, M. A., \& Kartiwi, M. (2015). The Predictive Accuracy of Sukuk Ratings; Multinomial Logistic and Neural Network Inferences. Pacific-Basin Finance Journal, 34, 273-292.

Azmat, S., Skully, M., \& Brown, K. (2017). The (Little) Difference that Makes All the Difference between Islamic and Conventional Bonds. Pacific-Basin Finance Journal, 42, 46-59.

Borhan, N. A., \& Ahmad, N. (2018). Identifying the Determinants of Malaysian Corporate Sukuk Tating. International Journal of Islamic and Middle Eastern Finance and Management .

Brigham, E. F., \& Ehrhardt, M. C. (2010). Study Guide for Brigham/Ehrhardt's Financial Management: Theory \& Practice: Nelson Education.

Brigham, E. F., \& Houston, J. F. (2006). Dasar-dasar manajemen keuangan, edisi 11. Jakarta: Salemba Empat.

Bursa Efek Indonesia (2017). Data Pasar Laporan Statistik Tahunan idx 2017. sumber: http://www.idx.co.id/data-pasar/laporan-statistik/statistik/ diakses pada 7 September 2018).

Bursa Efek Indonesia (2018). Data Perusahaan Tercatat. (sumber: http://www. idx.co.id/perusahaan-tercatat/profil-perusahaan-tercatat/ diakses pada 7 September 2018).

Bursa Efek Indonesia (2018). Data Pasar Obligasi dan Sukuk Korporasi. (sumber: http://www.idx.co.id/data-pasar/data-obligasi-sukuk/obligasi-sukukkorporasi/ diakses pada 7 September 2018).

Bursa Efek Indonesia (2018 ). Data Perusahaan Tercatat Laporan Keuangan dan Tahunan. (sumber: http://www.idx.co.id/perusahaan-tercatat/laporankeuangan-dan-tahunan/ diakses pada 7 September 2018).

Departemen Agama, R. (1989). al-Qur'an dan Terjemahnya. Semarang: Toha Putra.

Elhaj, M. A. A., Muhamed, N. A., \& Ramli, N. M. (2015). The Influence of Corporate Governance, Financial Ratios, and Sukuk Structure on Sukuk Rating. Procedia Economics and Finance, 31, 62-74.

Hamida, L. (2017). Pengaruh Likuiditas dan Leverage Terhadap Yield Sukuk dengan Peringkat Sukuk sebagai Variabel Intervening (Study Pada Perusahaan Non Keuangan di Bursa Efek Indonesia). Jurnal Ekonomi dan Bisnis, 18(1), 7186.

Hardwick, P., Adams, M., \& Burton, B. (2000). The Determinants of Credit Ratings in the United Kingdom Insurance Industry .

Hosmer, D. W., \& Lemeshow, S. (2000). Applied Logistic Regression. New York: John Wiley \& Sons.

Hosmer Jr, D. W., Lemeshow, S., \& Sturdivant, R. X. (2013). Applied Logistic Regression (Vol. 398): John Wiley \& Sons.

J,L.P.(2008). Encyclopedia ofSurvey Research Methods.doi:10.4135/9781412963947

Kamarudin, M. F., Kamaluddin, N., Manan, S. K. A., \& Ghani, G. M. (2014). Defaulters Profile in Malaysia Sukuk Market. Procedia-Social and Behavioral Sciences, 145, 277-285.

Keuangan, O. J. (2018). Statistik Pasar Modal minggu ke-5 2018. Diakses pada 1 September 2018.

Lavrakas, P. J. (2008). Encyclopedia of Survey Research Methods. doi: $10.4135 / 9781412963947$ 
Pebruary, S. (2016). Pengaruh Rasio Profitabilitas, Rasio Likuiditas, Rasio Leverage dan Pendapatan Bunga Terhadap Rating Sukuk Korporasi Periode 2010-2013. Jurnal Dinamika Ekonomi \& Bisnis, 13(1).

Qizam, I., \& Fong, M. (2019). Developing Financial Disclosure Quality in Sukuk and Bond Market: Evidence from Indonesia, Malaysia, and Australia. Borsa Istanbul Review, 19(3), 228-248.

Riyadi, S., Iqbal, M., \& Lauren, N. (2015). Strategi Pengelolaan Non Performing Loan (NPL) Bank Umum yang Go Public. Jurnal Dinamika Manajemen, 6(1).

Rozi, F. (2010). Sofie . 2010.Analisis Faktor-Faktor Yang Mempengaruhi Prediksi Peringkat Obligasi Syariah (Sukuk). Jurnal Akuntansi Islam, 1(1).

Saputri, D. A. (2017). Pengaruh Kinerja Keuangan terhadap Rating Sukuk dengan Menggunakan Model Regresi Multinomial Logistik Tahun 2013-2015. Universitas Airlangga.

Sari, I. K., \& Yasa, G. W. (2016). Pengaruh Penerapan Good Corporate Governance, Profitabilitas Dan Likuiditas Terhadap Peringkat Obligasi. E-Jurnal Akuntansi ,2198-2224.

Sharif, A. R. A., \& Abdullah, A. (2018). Impact of Time Value of Money Theory in Ijarah Sukuk Genuineness: the Case of Bahrain and Malaysia. International Business Research, 11(7), 56-63.

Sucipta, N. K. S. N., \& Rahyuda, H. (2015). Pengaruh pertumbuhan perusahaan, likuiditas, dan maturity terhadap peringkat obligasi perusahaan di bursa efek indonesia. E-Jurnal Manajemen, 4(3).

Sudaryanti, N., Mahfud, A. A., \& Wulandari, R. (2014). Analisis determinan peringkat sukuk dan peringkat obligasi di Indonesia. Tazkia Islamic Finance and Business Review, 6(2).

Utami, E. S., Anitasari, D., \& Endhiarto, T. (2017). Determinants of Corporate Bond Rating in Indonesia: Additional Evidence. Review Of Management And Entrepreneurship, 1(2), 27-33.

Widiastuti, N. P. T., \& Rahyuda, H. (2016). Pengaruh Pertumbuhan Perusahaan, Rasio Likuiditas, Maturity, dan Rasio Aktivitas terhadap Peringkat Obligasi pada Perusahaan Jasa. E-Jurnal Manajemen, 5(11).

Yaakub, N. I., Shah, H., Mujani, W. K., Jusoff, K., \& Hamid, M. A. (2011). Asset Ownership and Investor's Protection under Sukuk Ijarah. Middle-East Journal of Scientific Research (Special Issue of Diversity of Knowledge on Middle East), 7, 22-30. 


\section{APPENDIX \\ Research Samples}

\begin{tabular}{|c|c|c|}
\hline NO. & ISSUER & Obligation and Sukuk \\
\hline 1. & PT Indosat Tbk. (ISAT) & Sukuk Ijarah II Phase II Series A 2017 \\
\hline 2. & PT XL AXIATA Tbk. (EXCL) & Sukuk Ijarah I Phase I Series B I 2015 \\
\hline 3. & $\begin{array}{c}\text { PT Perusahaan Listrik Negara (Persero) } \\
\text { (PPLN) }\end{array}$ & Sukuk Ijarah I Phase II Series A 2013 \\
\hline 4. & PT Summarecon Agung Tbk. (SMRA) & Sukuk Ijarah I Phase I 2013 \\
\hline 5. & PT Indosat Tbk. (ISAT) & Sukuk Ijarah V 2012 \\
\hline 6. & PT Indosat Tbk. (ISAT) & Sukuk Ijarah I Phase IV Series B 2016 \\
\hline 7. & PT Summarecon Agung Tbk. (SMRA) & Sukuk Ijarah I Phase II 2014 \\
\hline 8. & PT Indosat Tbk. (ISAT) & Sukuk Ijarah I Phase I Series B 2014 \\
\hline 9. & $\begin{array}{c}\text { PT Perusahaan Listrik Negara (Persero) } \\
\text { (PPLN) }\end{array}$ & Sukuk Ijarah IV Series B 2010 \\
\hline 10. & PT XL AXIATA Tbk. (EXCL) & Sukuk Ijarah I Phase II Series B 2017 \\
\hline 11. & PT Indosat Tbk. (ISAT) & Sukuk Ijarah I Phase II Series C 2015 \\
\hline 12. & PT Aneka Gas Industri Tbk. (AGII) & Sukuk Ijarah I Phase I Series A 2017 \\
\hline 13. & $\begin{array}{c}\text { PT Perusahaan Listrik Negara (Persero) } \\
\text { (PPLN) }\end{array}$ & Sukuk Ijarah I Phase I 2013 \\
\hline 14. & PT Global Mediacom Tbk. (BMTR) & Sukuk Ijarah I Phase II 2017 \\
\hline 15. & PT Timah Tbk. (TINS) & Sukuk Ijarah I Phase I Series A 2017 \\
\hline 16. & PT Indosat Tbk. (ISAT) & Sukuk Ijarah II Phase II Series B 2017 \\
\hline 17. & PT XL AXIATA Tbk. (EXCL) & Sukuk Ijarah I Phase I Series C 2015 \\
\hline 18. & PT Aneka Gas Industri Tbk. (AGII) & Sukuk Ijarah I Phase II Series A 2017 \\
\hline 19. & PT Indosat Tbk. (ISAT) & Sukuk Ijarah I Phase IV Series C 2016 \\
\hline 20. & PT Indosat Tbk. (ISAT) & Sukuk Ijarah I Phase I Series C 2014 \\
\hline 21. & PT XL AXIATA Tbk. (EXCL) & Sukuk Ijarah I Phase II Series C 2017 \\
\hline 22. & PT Indosat Tbk. (ISAT) & Sukuk Ijarah Phase II Series D 2015 \\
\hline 23. & PT Aneka Gas Industri Tbk. (AGII) & Sukuk Ijarah I Phase I Series B 2017 \\
\hline 24. & PT Global Mediacom Tbk. (BMTR) & Sukuk Ijarah I Phase I Series A 2017 \\
\hline 25. & $\begin{array}{c}\text { PT Perusahaan Listrik Negara (Persero) } \\
\text { (PPLN) }\end{array}$ & Sukuk Ijarah Phase I Series A 2017 \\
\hline 26. & PT Timah Tbk. (TINS) & Sukuk Ijarah I Phase I Series B 2017 \\
\hline 27. & $\begin{array}{c}\text { PT Perusahaan Listrik Negara (Persero) } \\
\text { (PPLN) }\end{array}$ & Sukuk Ijarah II Phase II Series A 2017 \\
\hline 28. & PT Indosat Tbk. (ISAT) & Sukuk Ijarah II Phase II Series C 2017 \\
\hline 29. & PT XL AXIATA Tbk. (EXCL) & Sukuk Ijarah I Phase I Series D 2015 \\
\hline 30. & PT Aneka Gas Industri Tbk. (AGII) & Sukuk Ijarah I Phase II Series B 2017 \\
\hline 31. & PT Indosat Tbk. (ISAT) & Sukuk Ijarah I Phase III Series A 2015 \\
\hline 32. & PT Global Mediacom Tbk. (BMTR) & Sukuk Ijarah I Phase I Series B 2017 \\
\hline 33. & PT ANGKASA PURA I (PERSERO) (APAI) & Sukuk Ijarah I Series B 2016 \\
\hline 34. & $\begin{array}{c}\text { PT Perusahaan Listrik Negara (Persero) } \\
\text { (PPLN) }\end{array}$ & Sukuk Ijarah I PLN Phase II Series B 2013 \\
\hline 35. & PT XL AXIATA Tbk. (EXCL) & Sukuk Ijarah I Phase II Series D 2017 \\
\hline 36. & PT Indosat Tbk. (ISAT) & Sukuk Ijarah II Phase I Series C 2017 \\
\hline 37. & PT Global Mediacom Tbk. (BMTR) & Sukuk Ijarah I Phase I Series C 2017 \\
\hline 38. & PT Indosat Tbk. (ISAT) & Sukuk Ijarah II Phase II Series D 2017 \\
\hline 39. & PT Indosat Tbk. (ISAT) & Sukuk Ijarah I I Phase II Series E 2015 \\
\hline
\end{tabular}




\begin{tabular}{|c|c|c|}
\hline NO. & ISSUER & Obligation and Sukuk \\
\hline 40. & PT Indosat Tbk. (ISAT) & Sukuk Ijarah I Phase III Series B 2015 \\
\hline 41. & PT Indosat Tbk. (ISAT) & Sukuk Ijarah I Phase IV Series D 2016 \\
\hline 42. & PT ANGKASA PURA I (PERSERO) (APAI) & Sukuk Ijarah I Phase I Series C 2016 \\
\hline 43. & PT XL AXIATA Tbk. (EXCL) & Sukuk Ijarah I Phase II Series E 2017 \\
\hline 44. & PT Indosat Tbk. (ISAT) & Sukuk Ijarah II Phase I Series D 2017 \\
\hline 45. & $\begin{array}{c}\text { PT Perusahaan Listrik Negara (Persero) } \\
\text { (PPLN) }\end{array}$ & Sukuk Ijarah II Phase I Series B 2017 \\
\hline 46. & $\begin{array}{l}\text { PT Adira Dinamika Multi Finance Tbk. } \\
\text { (ADMF) }\end{array}$ & Sukuk Mudharabah III Phase I Series A 2017 \\
\hline 47. & PT Bank Maybank Indonesia Tbk. (BNII) & Sukuk Mudharabah I Phase II 2016 \\
\hline 48. & $\begin{array}{l}\text { PT Adira Dinamika Multi Finance Tbk. } \\
\text { (ADMF) }\end{array}$ & $\begin{array}{c}\text { Sukuk Mudharabah II Phase II Tahun } 2016 \\
\text { Series B }\end{array}$ \\
\hline 49. & $\begin{array}{l}\text { PT AdiraDinamika Multi Finance Tbk. } \\
\text { (ADMF) }\end{array}$ & Sukuk Mudharabah II Phase III Series B 2017 \\
\hline 50. & PT Bank Maybank Indonesia Tbk. (BNII) & Sukuk Mudharabah II Phase I 2017 \\
\hline 51. & $\begin{array}{l}\text { PT Adira Dinamika Multi Finance Tbk. } \\
\text { (ADMF) }\end{array}$ & Sukuk Mudharabah III Phase I Series B 2017 \\
\hline 52. & BPD Sumatera Barat (Bank Nagari) (BSBR) & Sukuk Mudharabah II 2015 \\
\hline 53. & $\begin{array}{c}\text { BPD Sulawesi Selatan Dan } \\
\text { Barat (Bank Sulselbar) (BSSB) }\end{array}$ & Sukuk Mudharabah II 2016 \\
\hline 54. & $\begin{array}{l}\text { PT Adira Dinamika Multi Finance Tbk. } \\
\text { (ADMF) }\end{array}$ & Sukuk Mudharabah II Phase II Series C 2016 \\
\hline 55. & $\begin{array}{l}\text { PT Adira Dinamika Multi Finance Tbk. } \\
\text { (ADMF) }\end{array}$ & $\begin{array}{l}\text { Sukuk Mudharabah II Phase III Series C } \\
2017\end{array}$ \\
\hline 56. & $\begin{array}{l}\text { PT Adira Dinamika Multi Finance Tbk. } \\
\text { (ADMF) }\end{array}$ & Sukuk Mudharabah III Phase I Series C 2017 \\
\hline 57. & PT Indosat Tbk. (ISAT) & Bond I Phase III Series A 2015 \\
\hline 58. & PT Indosat Tbk. (ISAT) & Bond VIII Series A 2012 \\
\hline 59. & $\begin{array}{c}\text { PT Perusahaan Listrik Negara (Persero) } \\
\text { (PPLN) }\end{array}$ & Bond I Phase II Series A 2013 \\
\hline 60. & $\begin{array}{l}\text { PT Adira Dinamika Multi Finance Tbk. } \\
\text { (ADMF) }\end{array}$ & Bond II Phase II Series C 2013 \\
\hline 61. & PT Maybank Indonesia Finance (BIIF) & Bond I Phase II Series A 2016 \\
\hline 62. & PT Summarecon Agung Tbk. (SMRA) & Bond I Phase I 2013 \\
\hline 63 & PT Indosat Tbk. (ISAT) & Bond II IPhase II Series A 2017 \\
\hline 64. & $\begin{array}{l}\text { PT Adira Dinamika Multi Finance Tbk. } \\
\text { (ADMF) }\end{array}$ & Bond IV Phase I Series A 2017 \\
\hline 65. & PT PP Properti Tbk. (PPRO) & Bond I Series A 2016 \\
\hline 66. & PT Summarecon Agung Tbk. (SMRA) & Bond I Phase II 2014 \\
\hline 67. & PT Maybank Indonesia Finance (BIIF) & Bond I Phase III Series A 2016 \\
\hline 68. & $\begin{array}{l}\text { PT Adira Dinamika Multi Finance Tbk. } \\
\text { (ADMF) }\end{array}$ & Bond III Phase III Series B 2016 \\
\hline 69. & PT Aneka Gas Industri Tbk. (AGII) & Bond I Phase I Series A 2017 \\
\hline 70. & Bank Victoria International Tbk. (BVIC) & Subordinate Bond III Fixed Interest 2013 \\
\hline 71. & $\begin{array}{l}\text { PT Perusahaan Listrik } \\
\text { Negara (Persero) (PPLN) }\end{array}$ & Bond I Phase I Series A 2013 \\
\hline 72. & $\begin{array}{c}\text { PT Perusahaan Listrik Negara (Persero) } \\
\text { (PPLN) }\end{array}$ & Bond XI Series B 2010 \\
\hline 73. & BPD Sumatera Barat (Bank Nagari) (BSBR) & Bond VII 2015 \\
\hline
\end{tabular}




\begin{tabular}{|c|c|c|}
\hline NO. & ISSUER & Obligation and Sukuk \\
\hline 74. & PT Maybank Indonesia Finance (BIIF) & Bond I Phase II Series B 2016 \\
\hline 75. & PT Maybank Indonesia Finance (BIIF) & Bond I Phase IV Series A 2017 \\
\hline 76. & PT Indosat Tbk. (ISAT) & Bond I Phase III Series B 2015 \\
\hline 77. & $\begin{array}{l}\text { PT Adira Dinamika Multi Finance Tbk. } \\
\text { (ADMF) }\end{array}$ & Bond III Phase VI Series B 2017 \\
\hline 78. & PT Summarecon Agung Tbk. (SMRA) & Bond II Phase II 2017 \\
\hline 79. & $\begin{array}{l}\text { PT Adira Dinamika Multi Finance Tbk. } \\
\text { (ADMF) }\end{array}$ & Bond III Phase II Series C 2015 \\
\hline 80. & PT Global Mediacom Tbk. (BMTR) & Bond I Phase II 2017 \\
\hline 81. & PT Aneka Gas Industri Tbk. (AGII) & Bond I Phase II Series A 2017 \\
\hline 82. & PT TimahTbk. (TINS) & $\begin{array}{l}\text { Bond I Phase I } \\
\text { Series A } 2017\end{array}$ \\
\hline 83. & Bank Victoria International Tbk. (BVIC) & Bond I Phase I 2017 \\
\hline 84. & PT PP Properti Tbk. (PPRO) & Bond I Series B 2016 \\
\hline 85. & PT Aneka Gas Industri Tbk. (AGII) & Bond I Phase I Series B 2017 \\
\hline 86. & PT Indosat Tbk. (ISAT) & Bond VIII Tahun 2012 Series B \\
\hline 87. & PT Global Mediacom Tbk. (BMTR) & Bond I Phase I Series A 2017 \\
\hline 88. & $\begin{array}{l}\text { PT Adira Dinamika Multi Finance Tbk. } \\
\text { (ADMF) }\end{array}$ & Bond III Phase IV Series C 2016 \\
\hline 89. & PT Bank Maybank Indonesia Tbk. (BNII) & Bond II Phase I Series A 2017 \\
\hline 90. & $\begin{array}{l}\text { BPD Sulawesi Selatan Dan Barat (Bank } \\
\text { Sulselbar) (BSSB) }\end{array}$ & Bond I Phase I 2016 \\
\hline 91. & $\begin{array}{l}\text { BPD Sulawesi Selatan Dan Barat (Bank } \\
\text { Sulselbar) (BSSB) }\end{array}$ & Bond I Phase II 2016 \\
\hline 92. & PT ANGKASA PURA I (PERSERO) (APAI) & Bond I Series A 2016 \\
\hline 93. & PT Angkasa Pura II (Persero) (APIA) & Bond I Series B 2016 \\
\hline 94. & PT Angkasa Pura II (Persero) (APIA) & Bond I Series A2016 \\
\hline 95. & PT Maybank Indonesia Finance (BIIF) & Bond I Phase IV Series B 2017 \\
\hline 96. & $\begin{array}{c}\text { PT Perusahaan Listrik Negara (Persero) } \\
\text { (PPLN) }\end{array}$ & Bond I Phase I Series B 2013 \\
\hline 97. & $\begin{array}{l}\text { PT Adira Dinamika Multi Finance Tbk. } \\
\text { (ADMF) }\end{array}$ & Bond III Phase VI Series C 2017 \\
\hline 98. & PT Global Mediacom Tbk. (BMTR) & Bond I Phase I Series B 2017 \\
\hline 99. & PT Aneka Gas Industri Tbk. (AGII) & Bond I Phase II Series B 2017 \\
\hline 100. & PT Timah Tbk. (TINS) & $\begin{array}{l}\text { Bond I Phase I } \\
\text { Series B } 2017\end{array}$ \\
\hline 101. & PT Global Mediacom Tbk. (BMTR) & Bond I Phase I Series C 2017 \\
\hline 102. & $\begin{array}{c}\text { PT Perusahaan Listrik Negara (Persero) } \\
\text { (PPLN) }\end{array}$ & Bond II Phase I Series C 2017 \\
\hline 103. & $\begin{array}{c}\text { PT Perusahaan Listrik Negara (Persero) } \\
\text { (PPLN) }\end{array}$ & $\begin{array}{l}\text { Bond II Phase II } \\
\text { Series C } 2017\end{array}$ \\
\hline 104. & PT Indosat Tbk. (ISAT) & Bond I Phase I Series D 2014 \\
\hline 105. & PT Indosat Tbk. (ISAT) & Bond I Phase II Series E 2015 \\
\hline 106. & PT Indosat Tbk. (ISAT) & Bond I IPhase III Series D 2015 \\
\hline 107. & PT Angkasa Pura II (Persero) (APIA) & Bond I Series C 2016 \\
\hline 108. & BPD Sumatera Barat (Bank Nagari) (BSBR) & Subordinate Bond II 2012 \\
\hline 109. & Bank Victoria International Tbk. (BVIC) & Subordinate Bond II 2012 \\
\hline 110. & Bank Victoria International Tbk. (BVIC) & Subordinate Bond I Phase I 2017 \\
\hline
\end{tabular}

